\title{
IMPLEMENTASI KATA TERIMAKASIH, TOLONG, DAN MAAF SEBAGAI \\ PEMBELAJARAN PESERTA DIDIK UNTUK MENANAMKAN JIWA \\ NASIONALISME DAN JATI DIRI BANGSA
}

\begin{tabular}{|c|}
\hline Muhammad Azhari Mutaqin \\
\hline $1910128210020 @$ mhs.ulm.ac.id \\
Program Studi Pendidikan Ilmu Pengetahuan Sosial \\
Fakultas Keguruan dan Ilmu Pendidikan \\
Universitas Lambung Mangkurat
\end{tabular}

\begin{abstract}
ABSTRAK
Artikel ini memiliki tujuan untuk memaparkan perihal pendidikan karakter satu diantaranya melakukan implementasi pada kata terimakasih, tolong, dan maaf sebagai pembelajaran peserta didik untuk menanamkan jiwa nasionalisme dan jati diri bangsa. Pada penelitian ini penulis menggunakan metode kualitatif dengan melakukan kajian studi pustaka berdasarkan kajian yang dibahas yakni Implementasi Kata Terimakasih, Tolong, dan Maaf Sebagai Pembelajaran Peserta Didik Untuk Menanamkan Jiwa Nasionalisme. Pada hasil penelitian ini terlihat bahwa pendidikan karakter sangatlah penting untuk diajarkan kepada generasi bangsa, sebab bangsa yang berkarakter dan bermoral merupakan bangsa yang mencerminkan jati diri bangsa. Adapun pada penerapan kata terimakasih, tolong, dan maaf merupakan satu dari sekian banyak pembelajaran untuk menciptakan peserta didik yang berjiwa positif, memiliki rasa menghargai, dan berakhlak mulia.
\end{abstract}

\section{Kata kunci: Pendidikan, Bangsa, Peserta Didik}

\section{PENDAHULUAN}

Satu dari faktor keberhasilan sebuah bangsa adalah kemajuan dan perkembangan pendidikan yang baik. Adapun indikator keberhasilan pendidikan selalu berpaku pada masyarakat barat seperti Amerika dan Eropa yang selalu saja menjadi panutan dalam memajukan dunia pendidikan. Adapun masalah ini didapatkan dari beberapa data serta informasi mengenai kehebatan pada sektor pendidikan seperti model pembelajaran, hasilhasil penelitian, produk-produk lulusan dan sebagainya. Dewasa ini bangsa Indonesia masih berada dalam posisi negara berkembang yang sedang mencari berbagai cara dengan cara melihat sistem negara maju untuk dapat memajukan pendidikan yang ada di Indonesia. Praktik pendidikan pada semua jenjang harus dilaksanakan secara terencana dan sistematis untuk mencapai tujuan pendidikan nasional (Subiyakto, 2019). Sistem 
pendidikan di Indonesia berpacu dengan Sistem Pendidikan Nasional yang merupakan sistem pendidikan yang akan membawa Indonesia lebih baik dalam bidang pendidikan, perkembangan bangsa dan mengikuti arus globalisasi.

Berbicara tentang pendidikan tentunya tidak terlepas dari peserta didik. Adapun peserta didik merupakan satu dari unsur pendidikan yang mana menjadi faktor utama keberhasilan pendidikan di Indonesia. Kunci proses pendidikan dikatakan berhasil apabila peserta didik berhasil menerima materi serta hal yang terpenting yaitu berhasil menanamkan jiwa nasionalis dan berjiwa bangsa yang baik sesuai dengan tujuan dari Sistem Pendidikan Nasional. Adapun satu dari pembentukan jiwa nasionalis antara lain dengan memberika pembelajaran yang berlandaskan pendidikan karakter. Proses membelajarkan peserta didik menjadi orang yang berjiwa bangsa dan sesuai dengan jati diri bangsa memanglah rumit, akan tetapi penanaman jiwa nasionalis dan jati diri bangsa pada peserta didik bisa dilakukan dengan cara memberikan mengajarkan peserta didik untuk berprilaku baik sesuai dengan yang diajarkan pada pendidikan karakter. Adapun satu caranya yaitu memberikan pemahaman kepada peserta didik bahwa penggunaan kata dalam sehari-hari harus diperhatikan serta pada saat melakukan kegiatan dalam hal apapun, peserta didik sebaiknya berperilaku baik dengan menerapkan tiga kata yang dinilai sangat penting untuk ucapkan selama menjalani hidup yaitu kata terimakasih, tolong, dan maaf. Tiga kata tersebut mungkin sangat sepele, akan tetapi sangat mengandung banyak nilai moral di dalamnya yang menjadikan peserta didik berjiwa bangsa. Untuk itu penulis membuat artikel ini dengan bertujuan untuk mengimplementasikan kata terimakasih, tolong, dan maaf sebagai pembelajaran peserta didik untuk menamkan jiwa nasionalisme dan jati diri bangsa, sebab satu dari jati diri bangsa yaitu memiliki bangsa yang berkarakter dan bermoral.

\section{METODE PENELITIAN}

Metode yang digunakan penulis yaitu menggunakan metode kajian kepustakaan serta menggunakan penelitian kualitatif. Kajian kepustakaan adalah sebuah proses pencarian informasi-informasi yang berhubungan dengan topik dan tema yang menjadi pembahasan utama artikel ini. Untuk memperoleh informasi tersebut, penulis bisa mendapatkannya melalui karya ilmiah, buku-buku, skripsi, tesis, disertasi, internet dan sumber relavan lainnya. Adapun pada penelitian kualitatif digunakan karena penulis ingin 
menelaah lebih lanjut mengenai implementasi kata terimakasih, tolong, dan maaf sebagai pembelajara peserta didik untuk menanamkan jiwa nasionalisme dan jati diri bangsa dengan cara mendeskripsikan dalam bentuk kalimat, dengan sebuah konteks alamiah serta memanfaatkan beberapa metode-metode alamiah.

\section{HASIL DAN PEMBAHASAN}

Pendidikan karakter merupakan sebuah usaha sadar yang sudah terstruktur dan tersistem yang berasal dari lingkungan pembelajaran untuk perkembangan potensi manusia secara menyeluruh yang memiliki watak bermoral dan berakhlak, berkepribadian baik, serta bermanfaat bagi lingkungan dan masyarakat sekitar (Abbas, 2016). Dapat dipahami pendidikan karakter merupakan sebuah usaha yang sudah terencana yang ditujukan untuk membangun karakter seseorang agar kedepannya menjadi pribadi yang bermanfaat baik untuk diri sendiri ataupun untuk banyak orang. Adapun pendidikan karakter tentunya memiliki fungsi awal untuk mengembangkan potensi individu agar bisa menjalani kehidupannya dengan berkelakukan positif. Pada ruang lingkup pendidikan formal, pendidikan karakter di sekolah berfungsi untuk membentuk karakter peserta didik agar menjadi pribadi yang berakhlak mulia, tangguh, berperilaku baik, bermoral, dan menjadi orang yang penuh dengan toleransi antar sesama. Semua kegiatan pembelajaran tidak hanya menyentuh aspek kognitif, tetapi juga belajar dari perspektif psikologis (berorientasi pada manusia) untuk membentuk pribadi yang utuh, yang disebut pendidikan karakter (Syaharuddin, 2020).

Dewasa ini tentunya pembelajaran sudah banyak berpusat pada pembentukan moral peserta didik khususnya pada beberapa mata pelajaran bidang sosial. Pembentukan moral peserta didik pada hakikatnya agar menciptakan peserta didik yang baik serta mampu menjadi generasi penerus bangsa yang berkarakter agar terciptanya jati diri bangsa yang memiliki masyarakat bermoral. Adapun untuk menciptakan hal tersebut perlu adanya implementasi pendidikan karakter. Pendidikan moral diyakini dapat mempengaruhi sikap atau perilaku seseorang (Mutiani, 2021). Satu dari pembelajaran yang bisa di berikan oleh peserta didik yaitu dalam penerapan berbicara antara lain selalu mengucapkan kata terimakasih, tolong, dan maaf (Cahyaningrum, 2018). Membelajarkan peserta didik untuk mengucapkan kata terimakasih, tolong, dan maaf dapat membuat mereka menjadi orang dihargai orang lain pada masa yang masa depannya nanti. 
Adapun pemaknaan kata terimakasih, tolong, dan maaf yang memiliki keterkaitan dengan nasionalisme dan jati diri bangsa sebab dengan kata tersebut dirasa sangat penting untuk diucapkan dalam kehidupan sehari-hari. Pada era modern saat ini jati diri bangsa sangat turun disebabkan karena pada calon generasi bangsa memiliki moral yang dirasa kurang baik, akibat pengaruh dari mengikuti globalisasi ke arah yang buruk. Sederhananya para peserta didik saat ini sudah sangat mengenal dengan sosial media yang memiliki banyak pengaruh buruk jika tidak bijak dalam menggunakannya. Berdasarkan dari tinjauan pustaka, para masyarkat Indonesia saat ini sudah mulai mengalami penurunan karakter dengan tidak menghargai orang lain. Padahal dengan membelajarkan warga negara untuk perpendidikan dan bertanggung jawab dapat menumbuhkan toleransi dalam lingkungan multikultural seperti Indonesia (Abbas, 2013). Banyaknya ditemukan komentar buruk dari masyarakat Indonesia di sosial media menyebabkan identitas bangsa menjadi ternodai. Penggunaan kata terimakasih, tolong, dan maaf sudah tidak lagi digunakan oleh beberapa orang dan menganggap kata-kata tersebut tidak terlalu penting untuk diucapkan.

Menghargai orang lain merupakan sikap yang seharusnya dimiliki bangsa Indonesia sebab jati diri bangsa Indonesia adalah sikap toleransi yang tinggi. Pada kasus ini penulis ingin menelaah betapa pentingnya hal tersebut dan harus dibelajarkan kepada peserta didik yang notaben adalah generasi penerus bangsa. Adapun pemaknaan kata terimakasih, tolong, dan maaf sebagai kata yang memiliki keterkaitan besar dengan jati diri bangsa sebab peserta didik yang terbiasa mengucapkan kata-kata ini pastinya mempunyai kepribadian yang baik, menghargai orang lain dan percaya bahwa hidup di dunia ini tak akan mudah tanpa bantuan sesama manusia dan tentunya dapat mencerminkan bahwa Indonesia memiliki penerus bangsa yang baik (Bancin, 2020).

Kata "Terimakasih" adalah dua kata dengan satu makna. Terima bisa diartikan pada saat kita mendapatkan sesuatu yang bernilai baik bagi kita. Sebagai ungkapan rasa syukur kita kasih atau memberikan sesuatu terhadap orang yang sudah memberi kita. Bisa juga rasa syukur tersebut kita berikan pada orang lain. Jika direnungkan lebih lanjut kata ini memberikan makna yang sangat dalam. Inilah kata yang diciptakan oleh suatu bangsa yang berbudaya tinggi. Lalu kata "Tolong” merupakan kata yang diucapkan pada saat kita meminta sesuatu, dengan menambahkan kata tolong, kita sudah menghargai orang yang kita suruh atau minta, dengan begitu orang yang diminta tersebut merasa dihargai. 
Kemudian kata "Maaf" merupakan upaya yang dilakukan secara sungguh-sungguh untuk tidak mengulangi kesalahan yang sama, apalagi sama persis. Ini tidak saja dalam ucapan, ungkapan, dan tulisan. Tetapi yang lebih utama sikap nyata dalam kehidupan sehari-hari, yang terpenting adalah setelah berbuat salah dan khilaf sesegera mungkin meminta maaf dan memperbaikinya melalui perbuatan nyata, bukan sebatas retorika belaka.

Itulah makna dari kata terimakasih, tolong, dan maaf. Dapat dikatakan bahwa ketiganya adalah kata-kata ajaib, yang dapat digunakan untuk mempromosikan komunikasi dan memberikan rasa identitas nasional yang lebih baik. Hal ini juga dapat mencerminkan sikap saling menghormati, saling menghargai dan saling memelihara, simpati, dan peduli antar sesama manusia. Tidaklah sulit untuk memahami kekuatan dari ketiga kata ini dan menggunakannya dalam kehidupan sehari-hari, itu semua tergantung pada kemauan dan hati nurani kita untuk menciptakan kehidupan yang lebih baik melalui komunikasi yang benar. Sebuah negara yang dihiasi dengan pikiran positif, frase positif dan energi positif akan membawa kehidupan yang lebih baik dan lebih produktif.

Nasionalisme tidak hanya sebatas cinta tanah air dan mengenang sejarah kemerdekaan Indonesia, lebih dari itu penanaman jiwa nasionalis bisa dilakukan dengan penerapan kata-kata tersebut. Sebab, dengan menerapkan tiga kata tersebut peserta didik sudah menanamkan jiwa nasionalis karena bersikap sesuai dengan jati diri bangsa yaitu bangsa yang bermoral (Triana, 2018). Bangsa yang bermoral yaitu bangsa yang memelihara moralitas bangsanya sendiri. Adapun pemaknaan moral senantiasa menunjuk kepada manusia sebagai subyek etika (Mutiani, 2015). Seperti halnya para pemuda dan generasi penerus suatu negara, mereka memiliki pemahaman tertentu tentang sikap yang dapat menjaga moralitas dan perilaku. Oleh karena itu, generasi penerus bangsa dapat memiliki kepribadian dan akhlak yang baik.

Berbicara tentang bangsa yang berkarakter, tentunya harusnya memiliki Sumber Daya Manusia (SDM) yang berkarakter pula. Sumber Daya Manusia (SDM) merupakan aset terpenting dalam membangun negara yang lebih baik dan maju. Namun, untuk mencapai tujuan tersebut, sumber daya manusia kita harus memiliki individualitas. Sumber daya manusia dengan kepribadian yang kuat memiliki kemampuan psikologis yang berbeda dengan orang lain, seperti kehandalan, ketulusan, kejujuran, keberanian, keteguhan, keras kepala, ketaatan pada prinsip dan karakteristik unik lainnya. Oleh karena itu seorang pendidik sebaiknya memiliki tanggung jawab untuk menjadi panutan yang 
memiliki nilai moral dan menggunakan kesempatan untuk mempengaruhi peserta didik. Artinya pendidik di lingkungan sekolah harus mampu menjadi "uswah hasanah" yang hidup bagi setiap peserta. Mereka juga harus terbuka dan mau mendiskusikan nilai-nilai baik tersebut dengan siswa. Untuk itu pendidik bisa mulai mencontohkan untuk menerapkan kata terimakasih, tolong, dan maaf setiap proses pembelajaran agar bisa menjadi contoh untuk peserta didiknya dan membuat peserta didik mengikuti apa yang dilakukan pendidik tersebut. Sebab pendidik yang memberikan pendidikan karakter, tentunya berpotensi menciptakan peserta didik yang bermoral, pembelajaran moral sebagai bagian dari pendidikan nilai sekolah, dapat membantu peserta didik untuk mengenali dan memahami pentingnya nilai-nilai moral. Nilai-nilai moral harus dijadikan pedoman bagi sikap dan perilaku peserta didik sebagai manusia, baik dalam sekolah maupun bermasyarakat.

\section{SIMPULAN}

Pendidikan karakter menjadikan peserta didik sebagai bangsa yang berjiwa nasionalis dan mencipkatan jati diri bangsa yang bermoral dan berperilaku baik. Adapun peran dunia pendidikan dalam hal ini yaitu melakukan sebuah pembelajaran kepada peserta didik bahwa pendidikan karakter sangatlah penting untuk dipahami dan dipelajari untuk kehidupan peserta didik di masa yang akan datang, sebab mereka akan menjadi generasi penerus bangsa yang mana sebagai penerus bangsa harus memiliki etika yang baik agar mencerminkan jati diri bangsa. Sehubung dengan hal tersebut peserta didik diajarkan untuk bersikap dan berkomunikasi dengan baik satu diantaranya dengan menerapkan tiga kata ajaib yaitu kata terimakasih, tolong, dan maaf. Kata-kata tersebut walau dilihat sepele, sebenarnya memiliki banyak sekali makna yang terkandung di dalamnya yang menjadikan peserta didik jika menerapkan tiga kata itu dalam berkomunikasi selama hidupnya, maka akan dipastikan peserta didik tersebut menjadi orang yang hebat dan sudah mencerminkan jati diri bangsa. 


\section{DAFTAR PUSTAKA}

Abbas, E. W. (2013). Mewacakan Pendidikan IPS (Cetakan Kedua). Bandung: WAHANA Jaya Abadi.

Abbas, E. W., Wahyu, W., Sofyan, A., \& Sarbaini, S. S., \& Syaharuddin, S. (2016). Pendidikan Karakter. Bandung: WAHANA Jaya Abadi.

Bancin, E. C. N. (2020). Penerapan kata terima kasih, tolong, dan maaf dalam menanamkan kesantunan berbahasa siswa kelas I SD (Doctoral dissertation, Universitas Pelita Harapan).

Cahyaningrum, F., Andayani, A., \& Setiawan, B. (2018). Kesantunan Berbahasa Siswa dalam Berdiskusi. Madah, 9(1), 45-54.

Mutiani, M. (2015). Reaktualisasi Pengamalan Nilai Pancasila untuk Demokrasi Indonesia. SOSIO-DIDAKTIKA: Social Science Education Journal, 2(2), 176-183.

Mutiani, M., Sapriya, S., Handy, M. R. N., Abbas, E. W., \& Jumriani, J. (2021). Pembinaan Etika Peserta Didik Melalui Pembelajaran Tematik-Integratif Di Sekolah Dasar. Edukatif: Jurnal Ilmu Pendidikan, 3(3), 704-709.

Subiyakto, B., \& Mutiani, M. (2019). Internalisasi nilai pendidikan melalui aktivitas masyarakat sebagai sumber belajar ilmu pengetahuan sosial. Khazanah: Jurnal Studi Islam Dan Humaniora, 17(1), 137-166.

Syaharuddin, S., \& Mutiani, M. (2020). Strategi Pembelajaran IPS: Konsep dan Aplikasi. Banjarmasin: Program Studi Pendidikan IPS FKIP ULM.

Triana, L., \& Purwanto, B. E. (2018, December). Pembelajaran Kesantunan Berbahasa untuk Menunjukkan Jati Diri Bangsa Indonesia pada Era Global. In Pertemuan Ilmiah Bahasa Dan Sastra Indonesia (PIBSI) 2018. 